\title{
Scleromyxedema: A Case Report and Review of the Literature
}

\author{
Mohamed Allam Mohamed Ghozzi \\ Dermatology Department, Al Khor Hospital, Hamad Medical Corporation, Al Khor, Qatar
}

\section{Key Words}

Scleromyxedema $\cdot$ Paraproteinemia $\cdot$ Systemic sclerosis

\begin{abstract}
Scleromyxedema (SM) is a sclerotic variant of lichen or papular mucinosis in which lichenoid papules and scleroderma-like features are both present. It is a rare deposition disorder characterized by generalized papular and sclerodermoid eruptions, mucin deposition, increased fibroblast proliferation, fibrosis, and monoclonal gammopathy (also known as paraproteinemia) mainly of the immunoglobulin G-lambda type in the absence of thyroid disease. It usually affects middle-aged adults and shows no gender or racial predilection. In addition to the skin findings and paraproteinemia, patients with SM have variable multisystem affections that mimic systemic sclerosis; the systems which are commonly involved include the gastrointestinal tract, musculoskeletal, pulmonary, cardiovascular, renal, and central nervous systems, leading to significant morbidity and mortality. Prominent symptoms include dysphagia, proximal muscle weakness, and dyspnea on exertion; less common but important findings include central nervous system involvement in the form of encephalopathy, convulsions, coma, and psychosis.
\end{abstract}

\section{Introduction}

Scleromyxedema (SM) is one of the 3 forms of lichen myxedematosus that were proposed by Rongioletti in 2006 [1]. Rongioletti refined the old classification and proposed the following 3 forms of lichen myxedematosus: (1) the generalized papular and sclerodermoid variant (the only one that should be called SM); (2) localized forms further classified into 4 subtypes - discrete papular mucinosis, acral persistent papular mucinosis, papular mucinosis of infancy, and a nodular form, and (3) atypical or intermediate forms, including SM without monoclonal gammopathy, localized forms with monoclonal gammopathy and/or systemic symptoms, localized forms with mixed features of the subtypes, and variants that 
are not well specified $[1,2]$. The etiology of the disorder remains an enigma; the precise mechanisms whereby increased fibroblast activity results in mucin deposition remain to be defined [2,3]. To date, there is no completely satisfactory therapeutic approach to SM. The rarity of the disorder, combined with the lack of well-designed clinical trials studying the disease, translates to a 'therapeutic ladder' based on anecdotal reports and small cases series [3].

\section{Case Report}

A 47-year-old Sri Lankan man had a history of slow onset, generalized, symmetric papular lesions mostly located on the face, ears, neck, upper trunk, forearms, and hands (fig. 1, fig. 2 , fig. 3). The papules were set close together, measuring 2-3 $\mathrm{mm}$ in diameter, and arranged in a linear pattern. The dorsa of both hands showed clusters of papules (fig. 3). Our patient also had progressive induration, tightness, and infiltration of the skin; there was sclerodactyly, and the 'doughnut sign' was evident over the proximal interphalangeal joints due to infiltration of the skin (fig. 3). Additionally, he started to develop progressive proximal muscle weakness, arthralgia, dyspnea especially on exertion, and regurgitation and dysphagia which were the most annoying symptoms for him at the time of examination.

A biopsy was taken and revealed papillary dermal myxoid material (demonstrated by colloidal iron) with fibroblastic proliferation consistent with the diagnosis of scleroderma.

Laboratory investigations revealed the following: complete blood count and differential count were within normal range; erythrocyte sedimentation rate was $17 \mathrm{~mm} / 1 \mathrm{~h}$ (normal 015). Free thyroxin and thyroid stimulating hormone were within normal range. Protein electrophoresis showed the presence of a monoclonal band, about $5.2 \mathrm{~g} / \mathrm{l}$, which was typed and proved to be immunoglobulin G-lambda, after immunofixation; cholesterol $6.13 \mathrm{mmol} / \mathrm{l}$ (desirable <5.17); triglyceride $3.26 \mathrm{mmol} / \mathrm{l}$ (desirable <1.7); high-density lipoprotein 0.92 $\mathrm{mmol} / \mathrm{l}$ (<1.0 low); low-density lipoprotein $4 \mathrm{mmol} / \mathrm{l}$ (desirable <3.36); glucose, urea nitrogen, serum creatinine, uric acid, total bilirubin, alkaline phosphatase, calcium, and corrected calcium were within average range; total protein $84 \mathrm{~g} / \mathrm{l}$ (normal 60-80); phosphorus $1.52 \mathrm{mmol} / \mathrm{l}$ (normal 0.87-1.45); ALT (GPT) $49 \mathrm{U} / \mathrm{l}$ (normal 0-40); AST (GOT) $59 \mathrm{U} / \mathrm{l}$ (normal 0-37). It was recommended that the patient undergo radiological examination of the chest and esophagus, abdominal ultrasonography, electrocardiography, echocardiography, and electromyography of the deltoid muscle. Also, he was referred to ophthalmology, gastrointestinal, neurology, hematology and pulmonary departments for further assessment, bone marrow biopsy examination and pulmonary function tests. Unfortunately, the patient was lost to follow-up before these assessments and tests could be performed. The patient did not receive any medication due to loss to follow-up.

\section{Discussion}

SM should be distinguished as a separate entity, with specific diagnostic and therapeutic approaches different from those for other localized forms of lichen myxedematous. Such approaches should take into consideration the multiple systemic disorders associated with this entity and its possible fatal outcome.

The etiopathogenesis of SM and the cause of hyperproliferation of dermal fibroblasts, together with dermal mucin deposition and increased collagen deposition, are not clear. SM serum enhances the proliferation of dermal fibroblasts [4, 5]; however, the stimulating 
capacity remains even after the removal of the immunoglobulins, indicating that this stimulating capacity is not related to paraproteinemia. Paraproteinemia does not correlate with either extension or progression of the disease [6]. It has been suggested that a circulating factor other than paraproteinemia is responsible for fibroblast proliferation [4, 5]. Inherent altered growth regulation in dermal fibroblast regulation in SM has also been suggested [7-9].

Desai and James [10] suggest melphalan, systemic steroids, and plasmapheresis as firstline treatments. Second-line therapeutic options include isotretinoin, acitretin, and topical corticosteroids. Third-line strategies consist of the use of 2-chlorodeoxyadenosine, cyclophosphamide, cyclosporine, methotrexate, thalidomide, autologous stem cell transplantation, extracorporeal photopheresis, intravenous immunoglobulin (IVIG) therapy, interferon alfa-2b, psoralen plus ultraviolet A (PUVA) and radiation [11].

Melphalan has produced some remarkable results in several severe cases, but its use has been restricted because of toxicity [12-18]. PUVA, Grenz ray, and electron beam therapy have also been used with mixed results [19]. Variable results have been obtained with systemic steroids [20-32] and daily cyclophosphamide [33, 34]. Pulse cyclophosphamide was effective in 1 patient [35]. Etretinate and isotretinoin have been used with variable results [36, 37]. Good response to extracorporeal photochemotherapy after poor response to PUVA, plasmapheresis, isotretinoin, and chlorambucil with prednisone was described in 2 articles [38, 39]. Two patients responded well to plasmapheresis with concomitant immunosuppression $[40,41]$, whereas another patient did not respond to a single plasmapheresis procedure [42]. Cyclosporine was tried in 1 case report [7], based on reports of its beneficial effects in conditions (systemic sclerosis, morphea, and scleredema) that share similarities with SM [43]. Cyclosporine, through its immunosuppressive effects, could influence lymphokine and growth factor production, directly suppressing fibroblast proliferation and glycosaminoglycan synthesis [44].

High-dose therapy with melphalan followed by stem cell support is being used successfully in patients with myeloma [45]. Feasel et al. [46] were the first to report their experience with this modality in treating a patient with SM. They demonstrated significant improvement in his functional status and skin examination. Lacy et al. [47] retrospectively evaluated 6 patients with SM who were offered high-dose chemotherapy with stem cell rescue. They concluded that high-dose chemotherapy with stem cell rescue offers a durable remission in most patients, although it is not curative. They advise that this treatment be considered before treatment with alkylating agents or other treatments that could adversely affect the ability to harvest stem cells. Illa et al. [48] successfully treated a 66-year-old man with SM, associated with an immunoglobulin G-lambda paraprotein, with the BEAM regimen (BCNU, etoposide, cytarabine [Ara-C], and melphalan) and autologous stem cell transplantation. The patient fully recovered after 6 months and was still in remission 3 years after transplantation, although the $\mathrm{M}$ spike remained detectable. The authors chose this protocol because they hypothesized that this would help avoid the relapses observed in patients who received melphalan alone. They were also able to demonstrate that the proliferation rate of fibroblasts decreased with treatment, independent of immunoglobulins.

Several recent studies evaluated the efficacy of IVIG therapy in patients with SM and reported its dramatic initial results, which, however, need to be sustained with long-term, regular maintenance therapy. One study evaluated a case series of 10 patients with SM, highlighting their notable clinical, laboratory, and radiologic data, and documenting their experience with IVIG as the primary therapy [49]. They reported the successful use of IVIG as an initial therapy, with dramatic results, that needs long-term maintenance. The data from this study as well as those from others, demonstrate that the monoclonal antibody level was 
not reduced by IVIG therapy, and that the clinical manifestation of SM eventually relapses despite dramatic initial responses. However, it is also evident that repetitive retreatment with IVIG therapy can rapidly recapture control of the skin disease and other systemic symptoms for an extended period of time [50-53].

Rongioletti et al. [54] conducted a retrospective and prospective multicenter study to describe the characteristics of patients with SM, including the therapeutic interventions that were administered to them and their effectiveness. Their data supported the contention that IVIG is a relatively effective and safe treatment, the response is not permanent, and maintenance infusions are required. They also summarized (table 1) the different therapeutic regimens that were used in 25 patients and their effectiveness. Partial response was defined as a decrease in skin changes and improvement in systemic symptoms, and complete response as the disappearance of symptoms and no detectable skin findings on examination.

\section{References}

1 Rongioletti F: Lichen myxedematous (papular mucinosis): new concepts and perceptives for an old disease. Semin Cutan Med Surg 2006;25:100-104.

-2 Heymann WR: Scleromyxedema. J Am Acad Dermatol 2007;57:890-891.

-3 Cokonis Georgakis CD, Falasca G, Georgakis A, Heymann WR: Scleromyxedema. Clin Dermatol 2006;24:493497.

4 Harper RA, Rispler J: Lichen myxedematosus serum stimulates human skin fibroblast proliferation. Science 1978;199:545-547.

5 Yaron M, Yaron I, Yust I, Brenner S: Lichen myxedematosus (scleromyxedema) serum stimulates hyaluronic acid and prostaglandin E production by human fibroblasts. J Rheumatol 1985;12:171-175.

6 Chanda JJ: Scleromyxedema. Cutis 1979;24:549-552.

7 Bata-Csorgo Z, Husz S, Foldes M, et al: Scleromyxedema. J Am Acad Dermatol 1999;41:343-346.

-8 Trojanowska M, Wu LT, LeRoy EC: Elevated expression of c-myc proto-oncogene in scleroderma fibroblast. Oncogene 1988;3:477-481.

-9 Piccinini G, Luchetti MM, Canglia ML, et al: c-myc proto-oncogene is expressed by quiescent scleroderma fibroblasts and, unlike B-myc gene, does not correlate with proliferation. J Invest Dermatol 1996;106:12811286.

10 Desai AD, James WD: Lichen myxedematosus; in Lebwol MG, Heymann WR, Berth-Jones J, Coulson IC (eds): Treatment of Skin Disease: Comprehensive Therapeutic Strategies, ed 2. London, Elsevier, 2006, pp 343344.

11 Godby A, Bergstresser PR, Chaker B, Pandya AG: Fatal scleromyxedema: report of a case and review of literature. J Am Acad Dermatol 1998;38:289-294.

$\$ 12$ Fleming KE, Vermani D, Sutton E, et al: Scleromyxedema and the dermato-neuro syndrome: case report and review of the literature. J Cutan Pathol 2012;39:508-517.

13 Helm F, Helm TN: Iatrogenic mylemonocytic leukemia following melphalan treatment of scleromyxedema. Cutis 1987;39:219-223.

14 Feldman P, Shapiro L, Pick AI, Slatkin MH: Scleromyxedema, a dramatic response to melphalan. Arch Dermatol 1969;99:51-56.

15 Harris RB, Perry HO, Kyle RA, Winkelmann RK: Treatment of scleromyxedema with melphalan. Arch Dermatol 1979;115:295-299.

-16 Alligood TR, Burnett JW, Raines BL: Scleromyxedema associated with esophageal aperistalsis and dermal eosinophilia. Cutis 1981;28:60-64.

17 Chanda JJ: Melphalan therapy in the treatment of scleromyxedema. Arch Dermatol 1980;116:862-863.

18 Dinneen AM, Dicken CM: Scleromyxedema. J Am Acad Dermatol 1995;33:37-43.

19 Harris AO, Altman AR, Tschen JA, Wolf JE: Scleromyxedema. Int J Dermatol 1989;28:661-667.

-20 Jessen RT, Straight M, Becker LE: Lichen myxedematosus treatment with cyclophosphamide. Int J Dermatol 1978;17:833-839.

21 Truhan AP, Roenigk HH: Lichen myxedematosus: an unusual case with rapid progression and possible internal involvement. Int J Dermatol 1987;26:91-95.

22 Dubreuilh W: Fibromes miliaires folliculaires: sclerodermie consecutive. Ann Dermatol Syph 1906;37:569572.

-23 Reitmann K: Über eine eigenartige, der Sklerodermie nahestehende Affektion. Arch Dermatol Syph 1908;92:417-424. 
24 Montgomery H, Underwood LJ: Lichen myxedematosus (differentiation from cutaneous myxedemas or mucoid states). J Invest Dermatol 1953;20:213-236.

25 Gottron HA: Skleromyxödem (eine eigenartige Erscheinungsform von Myxothesaurodermie). Arch Dermatol 1954;199:71-91.

26 McCuiston SH, Schoch EP: Autopsy findings in lichen myxedematosus. Arch Dermatol 1956;74:259-262.

27 Rudner EJ, Mehregan A, Pinkus H: Scleromyxedema: variant of lichen myxedematosus. Arch Dermatol 1966;93:3-12.

28 Braun-Falco 0, Weidner F: Arndt-Gottron scleromyxedema with medullary plasmacytosis and myositis (in French). Arch Belges Dermatol Syphiligr 1970;26:193-217.

-29 Farmer ER, Hambrick GW Jr, Shulman LE: Papular mucinosis: a clinicopathological study of four patients. Arch Dermatol 1982;118:9-13.

-30 Donald GF, Hensley WJ, McGovern VJ: Lichen myxedematosus (papular mucinosis): a brief review of the literature and report of a case which failed to respond to ACTH and cortisone. Aust J Dermatol 1953;2:2834.

31 Perry HO, Montgomery H, Stickney JM: Further observations on lichen myxedematosus. Ann Intern Med 1960;53:955-969.

- 32 Dalton JE, Booth BH, Gray HR, Evans PV: Lichen myxedematosus (papular mucinosis). Arch Dermatol 1961;83:92-104.

33 Howsden SM, Herndon JH Jr, Freeman RG: Lichen myxedematosus: a dermal infiltrative disorder responsive to cyclophosphamide therapy. Arch Dermatol 1975;111:1325-1330.

-34 Liden S, Westermark P, Hilden JO, et al: Lichen myxedematosus with generalized nodular panniculitis. Acta Derm Venereol 1971;51:273-278.

-35 Aberer W, Wolff K: Skleromyxödem: immunsuppressive Therapie mit Zyklophosphamid. Hautarzt 1988;39:277-280.

-36 Milam CP, Cohen LE, Fenske NA, Ling NS: Scleromyxedema: therapeutic response to isotretinoin in three patients. J Am Acad Dermatol 1988;19:469-477. Brenner S, Yust I: Treatment of scleromyxedema with etretinate. J Am Acad Dermatol 1984;10:295-296.

38 Berkson M, Lazarus GS, Uberti-Benz M, Rook AH: Extracorporeal photochemotherapy: a potentially useful treatment for scleromyxedema. J Am Acad Dermatol 1991;25:724.

-39 Krasagakis K, Zouboulis CC, Owsianowski M, et al: Remission of scleromyxedema following treatment with extracorporeal photophoresis. Br J Dermatol 1996;135:463-466.

-40 McCarthy JR, Osserman E, Lombardo PC, Takatsuki K: An abnormal serum globulin in lichen myxedematosus. Arch Dermatol 1964;89:446-450.

41 MacFarlane AW, Davenport A, Verbov JL, et al: Scleromyxedema: successful treatment with plasma exchange and immunosuppression. Br J Dermatol 1987;117:653-657.

42 Westheim AI, Lookingbill DP: Plasmapheresis in a patient with scleromyxedema. Arch Dermatol 1987;123:786-789.

43 Clements PJ, Lachenbruch PA, Sterz M, et al: Cyclosporine in systemic sclerosis. Results of a forty-eight-week open safety study in ten patients. Arthritis Rheum 1993;36:75-83.

44 Ikeada H, Fujiwara K: Cyclosporin A and FK-506 in inhibition of rat Ito cell activation in vitro. Hepatol 1995;21:1161-1166.

45 Iranzo P, Lopez-Lerma I, Blade J, Rovira M, Herrero C: Scleromyxoedema treated with autologous stem cell transplantation. J Eur Acad Dermatol Venereol 2007;21:129-130.

-46 Feasel AM, Donato ML, Duvic M: Complete remission of scleromyxedema following autologous stem cell transplantation. Arch Dermatol 2001;137:1071-1072.

$\checkmark 47$ Lacy MQ, Hogan WJ, Gertz MA, Dispenzieri A, Rajkumar SV, Hayman S, et al: Successful treatment of scleromyxedema with autologous peripheral blood stem cell transplantation. Arch Dermatol 2005;141:1277-1282.

-48 Illa I, de la Torre C, Rojas-Garcia R, Altes A, Blesa R, Sierra J, et al: Steady remission of scleromyxedema 3 years after autologous stem cell transplantation: an in vivo and in vitro study. Blood 2006;108:773-774.

49 Blum M, Wigley FM, Hummers LK: Scleromyxedema: a case series highlighting long-term outcomes of treatment with intravenous immunoglobulin (IVIG). Medicine 2008;87:10-20.

50 Karim A, Lawlor F, Black MM: Successful treatment of scleromyxedema with high-dose intravenous immunoglobulin. Clin Exp Dermatol 2004;29:317-318.

51 Kulczycki A, Nelson M, Eisen A, Heffenan M: Scleromyxedema: treatment of cutaneous and systemic manifestations with high-dose intravenous immunoglobulin. Br J Dermatol 2003;149:1267-1281.

52 Lister RK, Jolles S, Whittaker S, Black C, et al: Scleromyxedema: response to high-dose intravenous immunoglobulin (hdIVIG). J Am Acad Dermatol 2000;43:403-408.

53 Righi A, Schiavon F, Jablonska S, et al: Intravenous immunoglobulins control scleromyxedema. Ann Rheum Dis 2002;61:59-61.

54 Rongioletti F, Merlo G, Cinotti E, Fausti V, et al: Scleromyxedema: a multicenter study of characteristics, comorbidities, course, and therapy in 30 patients. J Am Acad Dermatol 2013, E-pub ahead of print. 
Table 1. Treatment modalities in 25 patients with SM [54]

\begin{tabular}{|c|c|c|c|c|}
\hline Treatments & Patients & $\begin{array}{l}\text { Complete } \\
\text { response }\end{array}$ & $\begin{array}{l}\text { Partial } \\
\text { response }\end{array}$ & Failure \\
\hline Tried 1 & 14 & & & \\
\hline IVIG alone & & 3 & 3 & \\
\hline Steroids alone (PS/dexamethasone) & & & & 2 \\
\hline Thalidomide & & & 1 & \\
\hline Acitretin & & & 1 & \\
\hline Melphalan & & & & 1 \\
\hline Mycophenolate mofetil & & & & 1 \\
\hline PS + thalidomide & & & 1 & \\
\hline PS + hydroxychloroquine & & & 1 & \\
\hline Tried 2 & 3 & & & \\
\hline PS, followed by IVIG & & & $2^{*}$ & \\
\hline Hydroxychloroquine, followed by phototherapy & & & & 1 \\
\hline Tried 3 & 5 & & & \\
\hline PSL, followed by photopheresis, followed by IVIG & & & $1^{*}$ & \\
\hline MTX, followed by PS, followed by IVIG & & & $1^{*}$ & \\
\hline Phototherapy, followed by radiotherapy, followed by isotretinoin & & & & 1 \\
\hline Chloroquine, followed by etretinate, followed by interferon alfa- $2 \mathrm{~b}$ & & & & 1 \\
\hline Melphalan + PS, followed by photopheresis + PS + MTX, followed by radiotherapy & & & & 1 \\
\hline Tried 4 & 2 & & & \\
\hline $\begin{array}{l}\text { Hydroxychloroquine, followed by PS, followed by thalidomide, followed by IVIG + } \\
\text { lenalidomide }\end{array}$ & & $1^{\dagger}$ & & \\
\hline Thalidomide, followed by bath PUVA, followed by photopheresis, followed by PSL + IVIG & & & $1^{++}$ & \\
\hline Tried 5 & 1 & & & \\
\hline $\begin{array}{l}\text { Cyclosporine, followed by azathioprine, followed by cyclophosphamide, } \\
\text { followed by MTX + PS, followed by IVIG }\end{array}$ & & & $1^{*}$ & \\
\hline \multicolumn{5}{|c|}{$\begin{array}{l}\text { MTX = Methotrexate; PS = prednisone; PSL = prednisolone. }{ }^{*} \text { Caused by IVIG. }{ }^{\dagger} \text { Caused by IVIG + lenalidomide. }{ }^{++} \text {Caused by IVIG }+ \text { steroids } \\
\text { With a better understanding of the exact pathogenesis of SM and the mechanisms of newly emerged, more specific and directed therapies } \\
\text { especially in the era of biological treatment, we can help these patients receive more effective treatment with fewer side effects. In this } \\
\text { context, we would like to encourage more studies on the pathogenesis of SM, along with multicenter studies to assess the efficacy of } \\
\text { different treatment modalities, taking into consideration the rarity of this disease entity and its possible fatal outcome. }\end{array}$} \\
\hline
\end{tabular}




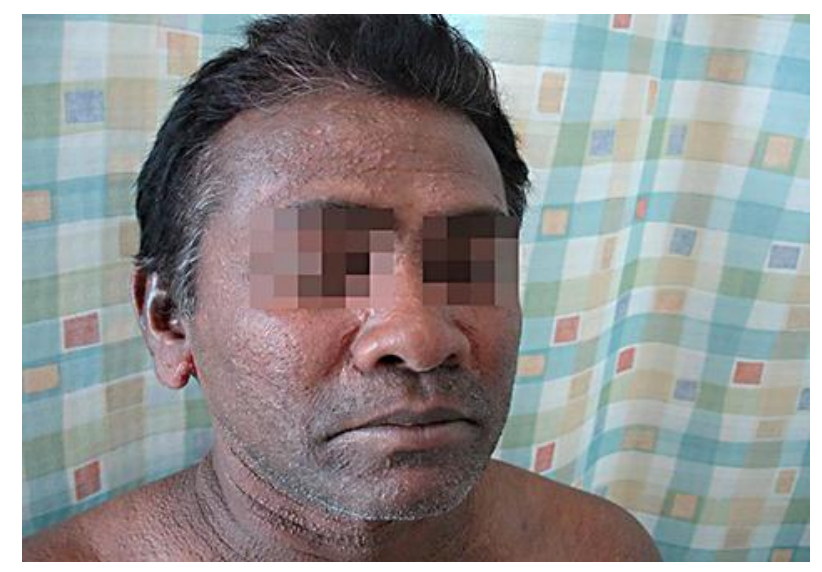

Fig. 1. Wide-spread, closely set papular eruptions, measuring 2-3 $\mathrm{mm}$, and arranged in a mostly linear pattern.

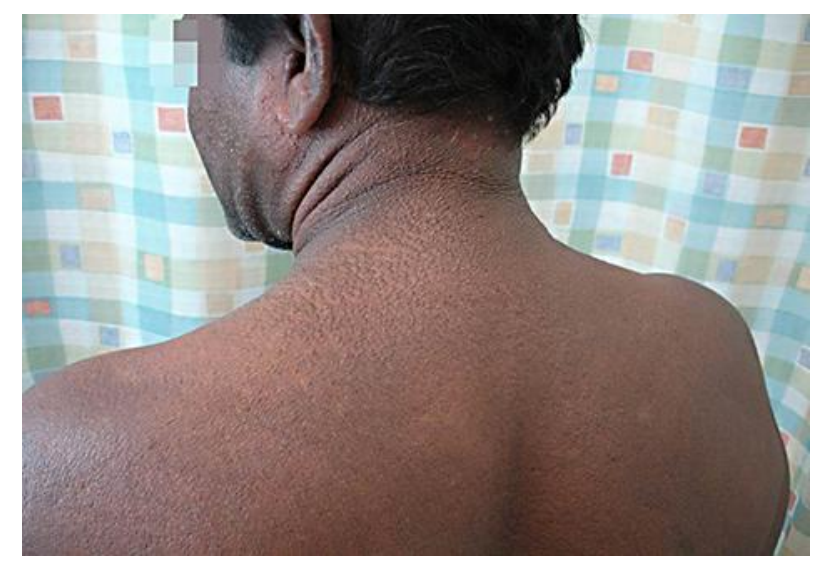

Fig. 2. Wide-spread papular eruptions, arranged in a linear pattern on the face, ears, neck, and upper back. 
Allam et al.: Scleromyxedema: A Case Report and Review of the Literature

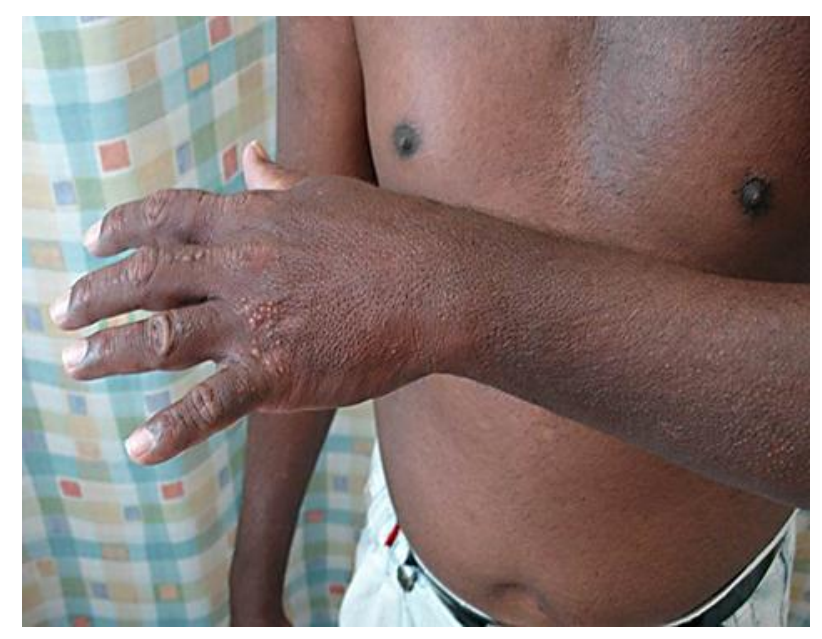

Fig. 3. Clusters of papules over the dorsum of the hand. Note the 'doughnut sign' over the proximal interphalangeal joints (arrow). 